\title{
Forest Economics Research Needs in West-Central Canada
}

\author{
William E. Phillips, James A. Beck and G. Wayne Lamble ${ }^{1}$
}

\begin{abstract}
A group of approximately 90 respondents, through sequential mail questionnaires and area group meetings, identified integrated forest land use, forest protection, allowable cut determination/timber supply analysis modelling, non-timber forest land uses, agricultural and forestry land use interface and forest renewal as among the more important needs requiring considerable economic research. Constraints in meeting these research needs include lack of research expertise, funding, data and problem definition, conflicting objectives and non-quantifiable benefits and costs.
\end{abstract}

Key Words: Forest economics, Research needs, Canada, Prairie Provinces/Northwest Territories, Delphi technique, Canadian Forestry Service, Research inventory, Nominal group technique, Research constraints.

\section{Résumé}

Un groupe d'environ 90 répondants ont permis d'identifier à la suite d'une série de questionnaires envoyés par la poste et de réunions de groupes par région que l'utilisation intégrée des terres forestières, la protection des forêts, les modèles d'analyse d'approvisionnement en bois et de calcul des possibilités de coupe, les utilisations des terres forestières contenant des bois immatures, les interactions reliées à l'utilisation des terres agricoles et forestières et la régénération forestière étaient parmi les plus importants sujets nécessitant d'amples recherches économiques. Les contraintes face à ces besoins de recherche comprennent le manque d'expertise dans ce domaine, le manque de fonds, le peu de précision du problème et des données qui y sont rattachées, les objectifs entrant en conflit et l'impossibilité de quantifier les coûts et les bénéfices.

Mots clés: Éducation forestière, besoin en recherche Canada, Provinces des Prairies, Territoires du Nord Ouest, technique Delphi, Service canadien des Forêts, inventaire de recherche, technique de groupe de base, contraintes de recherche.

\section{Introduction}

This paper highlights the results of a study by the authors (Phillips et al 1986) and funded by Canadian Forestry Service (CFS) in the form of a Program of Research by Universities in Forestry (PRUF) contract with the University of Alberta. The need for this study arose from a perception that forest economics research activities in the Prairie Provinces and Northwest Territories were found lacking, unfocussed and uncoordinated. There was also a perceived need for organizational development and coordination.

The purpose of the study was to determine forest economics research needs through the solicited responses of a panel of forest economics research participants and users. Objectives of the study were:

WW. Phillips is Professor, Department of Rural Economy, J. Beck is Professor and Chairman, Department of Forest Science, and W. Lamble is Professor, Faculty of Extension, University of Alberta, Edmonton, Alberta T6G $2 \mathrm{H} 1$.
1. to identify existing forest economics research activities;

2. to define forest economics research needs;

3. to define the gap between activities and needs;

4. to identify the constraints in meeting research needs; and

5. to strengthen a sense of community among the participants and users of forest economics research.

The focus of the exercise was on forest resource utilization. The interactive aspects such as recreational use of the forest, product development, surface and subsurface extraction on forest lands were recognized. It also included the social, economic and institutional interactivity of forest resource allocation. The spectrum of interest covered the forestry system from forest land resource base to final consumer demand.

This paper begins with a brief overview of the processes used to identify and assess forest economic research needs. 
However, the emphasis is on the research needs results per se which constitutes the balance of the paper.

\section{Methods}

Two techniques were employed in the study, the Delphi technique and the nominal group technique (Delbecq et al 1975; Simon 1960; and Thompson and Tuden 1959). Both techniques are designed for systematically soliciting and aggregating the judgements of a number of individuals on a particular topic to improve the quality of decision making.

The Delphi technique uses a set of carefully designed sequential questionnaires, interspersed with summarized information and feedback of opinions derived from earlier responses. To identify forest economics research needs, three sequential questionnaires were mailed to a sample of 88 leading users of forest economics research and forest economics researchers. The participants were selected using a peer nominating process. Since the Delphi technique does not require a face-to-face meeting, it was a convenient way of involving participants who are spread over a large geographical region.

The first round questionnaire asked participants to identify forest economics research needs that they felt should be addressed and the reasons for their selections. They were also asked to list any forest economics research projects with which they were familiar and to rate possible criteria for evaluating and rating forest economics research needs. Finally, the participants were asked to define their professional role, type of employment and geographic area of endeavour.

The second round questionnaire contained the list of research needs generated in the first round. Participants were asked to rate each one using a five-point scale from very low to very high in terms of importance and urgency criteria. The results identified areas of agreement and disagreement and provided an early awareness of preliminary priorities.

The third and final round questionnaire listed the identified forest economics research needs once again but now accompanied with the importance and urgency rating scores developed from round two results. Respondents were asked to provide a final rating of each item in terms of its overall importance. This final questionnaire completed this phase of the study and engendered a feeling among participants that their efforts were worthwhile by permitting them to vote on items developed and clarified in the previous rounds. Summary and analysis of the results of this Dephi phase resulted in three of the five study objectives being met, namely, identification of existing research activities and definitions of forest economics research needs and the gap between the activities and needs.

The second phase of the study involved an area meeting in each of the Prairie Provinces and the Northwest Territories. A modified nominal group technique was used. It is a groupcentered technique that structures a face-to-face group meeting by following a prescribed sequence of problemsolving steps. The objectives of the second phase were to provide further elaboration of the research needs identified in the first phase, to identify major constraints in conducting such research and to help strengthen a sense of community among the participants in forest economics research.

The meetings were conducted in a workshop format with the first part following the nominal group technique to select the top six priority research needs from the full listing of needs identified in the first phase. These priority items were then discussed in detail by sub-groups in the meetings to identify specific questions that should be addressed within each priority research topic and to identify major constraints in conducting such research. The reports of the sub-groups were discussed in plenary session. A discussion of the variations occurring between sub-regions with respect to research priorities concluded each meeting. Results of these meetings were carefully recorded and analyzed.

\section{Mail Survey Results}

A comprehensive list of past and current forest economics research activities was assembled (Phillips et al 1984). Most items pertain to forest industry impact, forest protection, non-timber forest land uses, forest industry structure and forest land use policy and planning studies.

The research activities provided by the mail survey participants, although not assumed to be complete, do represent the bulk of past and current forest economics research activites in the region. When compared with the research needs identified, activities fall short of fulfilling completely any of these needs, although significant beginnings have been made in some areas. For the most part, the gaps between the research needs and activities are very large. There is also a lack of cohesiveness in the existing research thrust. Results from this study could be used to initiate efforts to improve it.

Twenty-six major research needs were also identified. They included: (1) economics of integrated forest land use, (2) regional and economic forest industry impact, (3) economics of forest protection, (4) allowable cut determination and timber supply analysis modelling, (5) supply and demand modelling, (6) stumpage valuation, (7) economics of non-timber forest land uses, (8) intensive timber management alternatives, (9) forest industry structure analysis, (10) forest land use policy and planning studies, (11) economics of poplar utilization and (12) economics of environmental safeguards on forest land. These items are in order of priority for the region as a whole. Further details are given in Table 1.

A breakdown by region shows some variation (Table 2). Alberta's most important research needs are: (1) economics of integrated forest land use, (2) forest industry impact, (3) allowable cut determination and timber supply analysis modelling, (4) forest protection, (5) supply and demand modelling and (6) economics of non-timber forest land uses. Manitoba mail survey respondents provided: (1) economics of integrated forest land use, (2) forest protection, (3) forest industry impact, (4) supply and demand modelling, (5) economics of intensive timber management alternatives and (6) economics of non-timber forest land uses. The Northwest Territories respondents deviated most from the overall region priorities with: (1) economics of integrated forest land use, (2) forest protection, (3) socioeconomic analysis of the effects on trapping by timber harvesting and fire, (4) socioeconomic studies and Native forest land use issues, (5) forest industry impact and (6) economics of non-timber forest land uses. Saskatchewan participants revealed (1) forest industry impact, (2) economics of integrated forest land use, (3) economics of forest protection, (4) allowable cut determination and timber supply analysis modelling, (5) stumpage valuation and (6) economics of forest renewal. 
The top three research needs overall, (1) economics of integrated forest land use, (2) forest industry impact, and (3) economics of forest protection also ranked at or near the top for each area. Subsequent research needs tended to show considerable variation in rankings. Alberta and Manitoba rankings showed the greatest consistency with overall rankings. The one notable difference for Alberta is stumpage valuation, which ranked 6 th overall but 12 th for Alberta. Two notable differences exist for Manitoba. Economic analysis of forest industry structure ranked 9th overall but 16th for Manitoba and economics of poplar utilization ranked 11 th overall but 17 th for that province (Table 2).

The Northwest Territories (NWT) showed the greatest divergence from overall rankings. Allowable cut determination/timber supply analysis modelling ranked 4th overall but 10 th for the NWT; stumpage valuation ranked 6 th overall but 12th for the NWT; economics of intensive timber management alternatives ranked 8 th overall but $21 \mathrm{st}$ for the NWT; socioeconomic studies and Native forest land use issues ranked 16 th overall but 4 th for the NWT; and socioeconomic analysis of the effects on trapping of timber harvesting and fire ranked 24 th overall but 3rd for the NWT. The research needs priorities for the NWT are in many instances distinct from the Prairie Provinces (Table 2).

Saskatchewan registered three notable ranking differences from the overall rankings. Supply and demand modelling ranked 5 th overall but 11 th for Saskatchewan; economics of non-timber forest land uses ranked 7 th overall but only 17th for Saskatchewan; and finally, economics of forest renewal, which ranked 19th overall, is an important research need in Saskatchewan where it ranks 6th (Table 2).

Examination of area differences serves as a reminder that regional forest economic research needs priorities may need to be tempered by area priorities. For example, the research need which ranked 24 th overall and, on that basis alone, perhaps would be dropped from consideration, results in a significant oversight, namely, that it ranked 3rd for the Northwest Territories and thus merits consideration for that area (Table 2).

\section{Table 1. Forest economics research needs.}

1. Economics of integrated forest land use

Includes the application of benefit-cost analysis devoted to the relative economic importance of various forest land use patterns. Uses include commercial and non-commercial, consumptive and non-consumptive and environmental protection uses. Specifically, timber harvesting, grazing, wildlife and fisheries, watershed, outdoor recreation and tourism must be considered. The evaluation and interaction of such uses is made to assist planners and policy makers in deciding on various land use options and patterns.

2. Forest industry impact (regional/economic) Economic impact of the forest industry including value-added and multiplier effects on community, regional and provincial jurisdictions

3. Economics of forest protection

Benefit-cost analysis of alternative methods to determine optimum levels of expenditure for forest protection (prevention, detection and control) against loses from fire, insects and disease.

\section{Allowable cut determination/timber supply analysis modelling}

Research needs include:

a. The use of economic factors in the analysis,

b. Development of methodology and criteria to assist in optimum resource allocation determination for forest protection, management and processing,

c. The use of criteria that recognize the economics of harvesting and processing of small wood,

d. Computer modelling and other analytical techniques for forest utilization planning, and

e. Biometric growth modelling for inputs.

\section{Supply and demand modelling}

The modelling is to facilitate both short-term and long-term projections. Supply is to focus on regional, national and international forest resource availability, cost, and use. Demand is to focus on regional, national and international demands and to include price projections and studies of substitutes for forest products at various projected prices.

\section{Stumpage valuation}

Economic significance of alternative stumpage/royality pricing systems.

\section{Economics of non-timber forest land uses}

Studies include:

a. Losses to timber production due to non-timber uses,

b. Watershed protection benefits,

c. Fish and wildlife benefits and costs,

d. Outdoor recreation benefits and costs,

e. Tourism potential,

f. Wilderness parks, and

g. Feasibility of commercial recreation developments. 
8. Economics of intensive timber management alternatives

Studies of the biological response, economic costs and benefits and effects on society of various intensive management options including:

a. Determination of the allowable cut effect,

b. More intensive management of areas close to mills than on areas more distant from the mill,

c. Determination of priority stands for treatment,

d. Using genetically improved stock,

e. Increased protection levels,

f. Juvenile spacing,

g. Thinning or conversion of fire origin suppressed pine stands,

h. Use of herbicides for site preparation and release,

i. Thinning,

j. Mixed wood stand conversion,

k. Advanced roading, and

I. Fertilization.

9. Economic analysis of forestry industry structure

Studies are to include:

a. Analysis of the long-term viability of the forest industry including the costs and benefits of industry rationalization and the maintenance of a data base information system in each jurisdiction of the region,

b. Demand, supply, marketing and value-added analysis of producing secondary products from logs and pulp within the region,

c. Analysis of the economies of scale, technological change and input substitution, including capital versus labour, for various forestry operations including the sawmilling industry, and

d. Evaluation of alternative wood acquisition programs such as own roundwood production and purchased chips and wood.

10. Forest land use policy and planning studies

Studies to include:

a. Sustained yield - is it an economically viable policy objective,

b. The economics of forestry incentives and regulation,

c. Integration of forest harvesting into parks,

d. Inventory of timber including value of satelite imaginary versus manual cruising in forested land use planning,

e. Public perceptions of integrated resource use on public lands,

f. Use of physical, economic, social and political criteria in decision making.

g. Socioeconomic and environmental impact assessments effects or company operations,

h. Federal incentive and cost sharing programs,

i. Post-project evaluation,

j. Impact of allowable cut requirements on wood processing operations,

$\mathrm{k}$. Evaluation of institutional arrangements for forest industry regulation including industry stablization,

I. Forest management under public and private resource ownership, and

$\mathrm{m}$. Policy evaluation regarding effective use of softwood and hardwood.

11. Economics of poplar utilization

Studies on the economics of poplar utilization must include:

a. Market feasibility studies,

b. Product development studies, and

c. Determination of the economically available potential poplar supply,

12. Economics of environmental safeguards on forest land

Analysis of the costs and benefits, both dollar and non-dollar values, of various environmental safeguards such as:

a. Limits on use of pesticides,

b. Cutblock size limitations,

c. Buffer strips, and

d. Logging elevation limits.

13. Forest economics education

Review and analysis of curricula/course contents and methods to enhance understanding of forest economics.

14. Economics of timber accessibility and transportation

Analysis of the economics of transportation of forest products to include:

a. Determination of economically accessible stands,

b. Transport of finished products to market both domestic and export,

c. Government versus company built roads,

d. Winter versus summer hauling to mill, and

e. Determination of optimium road size.

15. Economic studies of timber resource utilization including smallwood

These studies are to be related to:

a. Harvesting costs,

b. Regeneration,

c. Timber values,

d. Conversion technology,

e. Merchantability standards,

f. Use of trash species, and

g. Determination of potential building log stands.

16. Socioeconomic studies and Native forest land use issues

Studies include:

a. Design of institutional arrangements for increased native business and employment opportunities in forest products,

b. Remote native community enhancement, and

c. Value of forests to traditional native lifestyles. 
17. Evaluation in economic terms of improved research, development and application of new technology

Such evaluation to include:

a. New production practices,

b. New genetic adaptations, and

c. New distribution practices

18. Economic analyses of agricultural and forestry land use interface

Such analyses include:

a. Evaluation of economic and social decision criteria for land allocation at the interface between forestry and agriculture,

b. Economic evaluation of local economy from a forestry-agricultural land use mix compared with an all-agriculture or all-forestry land use pattern,

c. Economics of utilizing forest land for agricultural purposes,

d. The costs and benefits to the forest industry from domestic grazing on reforested cut-over areas,

e. Analysis of the impact of transforming mixed wood areas to grazing through range improvement programs,

f. Comparison of productivity and technological change in terms of land using or land saving effects for agriculture and forestry

g. Evaluation of the status and prospects for forestry on private farm land, and

h. Economics of small woodiot operators.

19. Economics of forest renewal

Benefit-cost analysis of specific forest renewal techniques such as:

a. Spraying versus no spraying.

b. Juvenile spacing,

c. Container versus bare root planting,

d. Planting versus seeding,

e. Machine versus hand planting,

f. Contract versus own planting, and

g. Contract versus own nurseries.

20. Economics of wood energy utilization

Analysis of energy and forestry relationships including

a. Use of wood wastes for energy,

b. Use of biomass for energy

c. The relation between energy prices and timber demand, and

d. Use of peat for energy.

21. Timber product development

Studies including:

a. Solid wood products, and

b. Pulp products.

22. Forest products marketing studies

These studies are to include:

a. Analysis of the market potential and demand trends, both domestic and export, for new and existing products of the west central region,

b. Examination of alternative pricing methods for chips,

c. Development of an econometric model of the spruce-pine-fir lumber market, and

d. Analysis of alternative grading standards.

\section{Economics of milling technology}

Studies regarding:

a. Use of fire killed wood and jack pine for pulp.

b. Whole tree utilization,

c. Debarking,

d. Chipping, and

e. Screening

24. Socioeconomic analysis of the effects on trapping of timber harvesting and fire

25. Economics of harvesting technologies

Studies of the costs and benefits of various alternative harvesting technologies including:

a. Whole tree utilization,

b. New technologies including derrigibles, balloons, felling head, wide tires, etc.

c. Feller buncher and grapple skidding.

d. Delimbing and delimbers, and

e. Hand felling and cable skidding

26. Economics of urban forestry 
Table 2. Forest economics research needs in order of importance by region and sub-region

\begin{tabular}{|c|c|c|c|c|c|}
\hline Research need & Region & Alta. & Man. & NWT & Sask. \\
\hline 1. Economics of integrated forest land use & 1 & 1 & 1 & 1 & 2 \\
\hline 2. Forest industry impact (regional/economic) & 2 & 2 & 3 & 5 & 1 \\
\hline 3. Economics of forest protection & 3 & 4 & 2 & 2 & 3 \\
\hline 4. Allowable cut determination/timber supply analysis modelling & 4 & 3 & 8 & 10 & 4 \\
\hline 5. Supply and demand modelling & 5 & 5 & 4 & 7 & 11 \\
\hline 6. Stumpage valuation & 6 & 12 & 7 & 12 & 5 \\
\hline 7. Economics of non-timber forest land uses & 7 & 6 & 6 & 6 & 17 \\
\hline 8. Economics of intensive timber management alternatives & 8 & 9 & 5 & 21 & 7 \\
\hline 9. Economic analysis of forest industry structure & 9 & 7 & 16 & 12 & 8 \\
\hline 10. Forest land use policy and planning studies & 10 & 11 & 11 & 9 & 13 \\
\hline 11. Economics of poplar utilization & 11 & 8 & 17 & 15 & 12 \\
\hline 12. Economics of environmental safeguards on forest land & 12 & 16 & 10 & 16 & 10 \\
\hline 13. Forest economics education & 13 & 15 & 9 & 18 & 16 \\
\hline 14. Economics of timber accessibility and transportation & 14 & 19 & 18 & 12 & 9 \\
\hline 15. Economic studies of timber resource utilization including smallwood & 15 & 13 & 19 & 14 & 18 \\
\hline 16. Socioeconomic studies and Native forest land use issues & 16 & 20 & 12 & 4 & 23 \\
\hline $\begin{array}{l}\text { 17. Evaluation in economic terms of improved research, development and application of new } \\
\text { technology }\end{array}$ & 17 & 17 & 14 & 17 & 19 \\
\hline 18. Economic analysis of agricultural and forestry land use interface & 18 & 10 & 20 & 23 & 25 \\
\hline 19. Economics of forest renewal & 19 & 23 & 15 & 25 & 6 \\
\hline 20. Economics of wood energy utilization & 20 & 22 & 13 & 8 & 21 \\
\hline 21. Timber product development & 21 & 18 & 21 & 23 & 15 \\
\hline 22. Forest products marketing studies & 22 & 14 & 22 & 23 & 20 \\
\hline 23. Economics of milling technology & 23 & 21 & 23 & 19 & 13 \\
\hline 24. Socioeconomic analysis of the effects on trapping of timber harvesting and fire & 24 & 25 & 25 & 3 & 21 \\
\hline 25. Economics of harvesting technologies & 25 & 24 & 24 & 19 & 24 \\
\hline 26. Economics of urban forestry & 26 & 26 & 26 & 26 & 26 \\
\hline
\end{tabular}

\section{Area Meeting Results}

The area meeting workshops resulted in rankings of research needs that differed from mail survey rankings by area, in part, because area meeting proceedings allowed for combinations of two or more research needs into a single one and allowed for alterations of descriptions. The top six research needs selected are summarized by rank in Table 3 for each area. Numbering of research needs corresponds to that in Table 2. Except for Northwest Territories area meeting participants, each area group chose to combine two or three research needs into a single one. Each of the Alberta, Manitoba and Saskatchewan groups combined research needs number 7 , economics of non-timber forest land uses, and number 18, economic analysis of agricultural and forestry land use interface with number 1 , economics of integrated forest land use (1, 7 and 18). The Alberta group ranked it $1 \mathrm{st}$, the Manitoba group ranked it 3rd and the Saskatchewan group, 2nd (Table 3).

The Manitoba and Saskatchewan groups each combined number 8 , economics of intensive timber management alternatives, and number 19 , economics of forest renewal, into a single research need ( 8 and 19$)$. The Manitoba group ranked it $1 \mathrm{st}$ and the Saskatchewan group, 3rd. The group from Manitoba also combined number 16 , socioeconomic studies and Native forest land use issues, and number 24, socioeconomic analysis of the effects on trapping by timber harvesting and fire, into a single need (16 and 24) and ranked it 6 th. The Saskatchewan group combined number 4, allowable cut determination/timber supply analysis modelling, and number 14, economics of timber accessibility and transportation, into a single research need (4 and 14$)$ and ranked it 4 th. In total the Alberta group came up with one combination and the Manitoba and Saskatchewan groups each came up with three (Table 3).

To recap, Alberta area meeting participants identified and ranked first, economics of integrated forest land use including both timber and non-timber land uses and agricultural and forestry land use interface (numbers 1, 7 and 18); second, allowable cut determination and timber supply analysis modelling; third, economic analysis of forest industry structure; fourth tie, supply and demand modelling; fourth tie, forest land use policy and planning studies; sixth tie, forestry industry impact and sixth tie, economics of intensive timber management alternatives. The Manitoba group selected first, economics of intensive timber management alternatives including forest renewal (numbers 8 and 19); second, economics of forest protection; third, economics of forest land use (numbers 1, 7 and 18); fourth, forest industry impact; fifth, allowable cut determination and timber supply analysis modelling; and sixth, socioeconomic studies and Native forest land use issues including socioeconomic analysis of the effects on trapping of timber harvesting and fire (numbers 16 and 24). The Northwest Territories selected first, social and economic analysis of integrated forest land use; second, socioeconomic studies and Native land use issues; third, economics of forest protection; fourth, economics of nontimber forest land uses; fifth, socioeconomic analysis of the effects on hunting and trapping of timber harvesting and fires; and sixth, economics of wood energy utilization. Finally, the Saskatchewan group selected first, forest industry impact; second, economics of integrated forest land use including both timber and non-timber land uses and agricultural and forestry land use interface (numbers 1,7 and 18); third, economics of intensive timber management alternatives including forest renewal (numbers 8 and 19); fourth, allowable cut determination, timber supply analysis modelling and economics of timber accessibility and transportation (numbers 4 and 14); fifth, economics of forest protection; and sixth, economics of environmental safeguards on forest land.

The area meeting participants also identified several constraints on meeting the various research needs that included lack of research expertise, lack of funding, 
Table 3. Area meeting rankings of forest economics research needs.

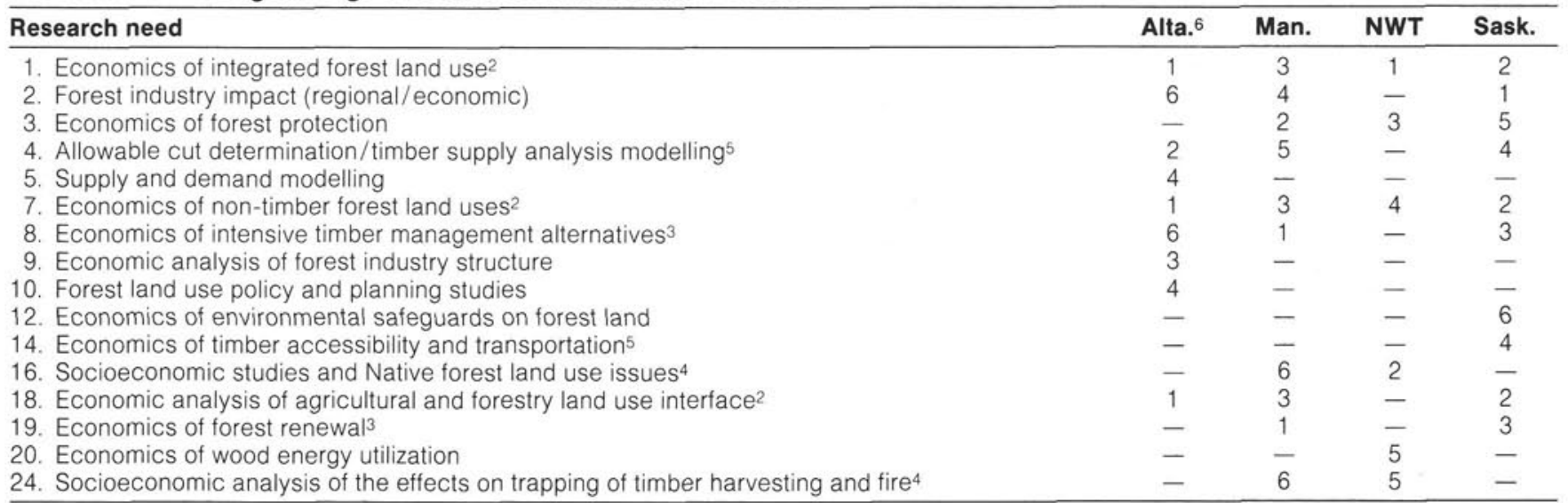

2Research need numbers 1,7 and 18 are combined into one item for Alberta, Manitoba and Saskatchewan.

3Research need numbers 8 and 19 are combined into one item for Manitoba and Saskatchewan.

${ }^{4}$ Research need numbers 16 and 24 are combined into one item for Manitoba.

sResearch need numbers 4 and 14 are combined into one item for Saskatchewan.

${ }^{6}$ Research need numbers 5 and 10 were tied for 4 th place and research need 2 and 8 tied for 6 th place.

conflicting objectives, non quantifiable benefits and costs, lack of data, and lack of problem definition and defined decision making processes. Also included were political constraints which included jurisdictional overlap, lack of awareness and lack of public commitment or acceptance. Cross cultural problems, language difficulties, communication gaps and hard positions in communities were also identified as constraints in meeting forest economics research needs.

\section{Conclusion}

A broad spectrum of forest economics needs has been identified. Past and current research, although important, has only begun to close the gaps between research activities and needs. In the opinion of the authors, there is no cohesive forest economics research thrust in the region. The results of the study provide considerable direction in establishing such a thrust. The authors hope that this study will be taken seriously to this end, that its usefulness not be limited to the Canadian Forestry Service which funded it, but extended to the forestry community at large.

This study has facilitated increased dialogue among different forest economics research interests. Efforts must be made to continue this process. Hopefully a means of ensuring continued dialogue, research inventory updating and research needs modifications can be found. Such efforts are essential to increase and maintain momentum in meeting forest economic research needs in the west-central region of Canada.

\section{Acknowledgement}

Funds from the Canadian Forestry Service through the Program of Research by Universities in Forestry were essential to the project. The assistance from M. Heit, D. Boylen, E. Gillespie, R. Dempster, J. Warren, C. Shier, J. Copeland, W. Williamson, S. Greenberg, V.Smyth, B. LeBlanc, D. Krystofiak, C. French, L. Ehrler and E. Novotny are gratefully acknowledged. Last, but not least, the input provided by the mail survey and area meeting participants is sincerely appreciated.

\section{References}

Delbecq, A.L., A.H. Van de Ven, and D.H. Gustafson. 1975. Group Techniques for Program Planning. Glenview, Illinois: Scott, Foresman and Company.

Phillips, W., J. Beck, and W. Lamble. 1986. Forest Economics Research Needs for the West Central Region of Canada. Information Bulletin. Edmonton: Canadian Forestry Service and University of Alberta (In press).

Simon, H.A. 1960. The New Science of Management Decisions. New York: Harper Brothers.

Thompson, J. and A. Tuden. 1959. "Strategies, structures, and processes of organizational decisions." In J. Thompson et al (Eds.), Comparative Studies in Administration. Pittsburgh: University of Pittsburgh Press.

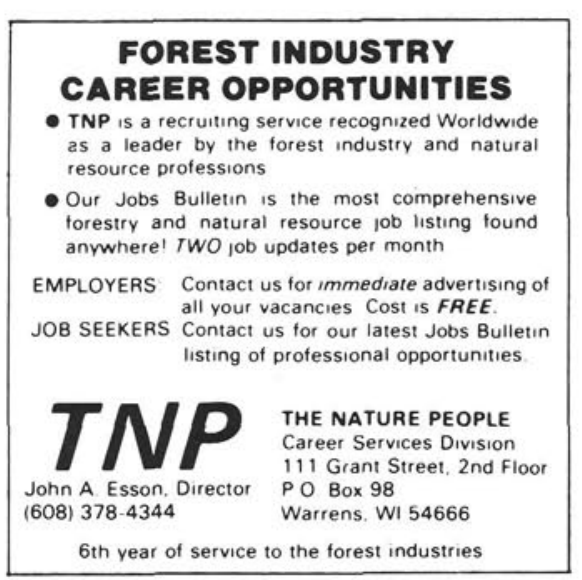

